\title{
Trisomy 21
}

National Cancer Institute

\section{Source}

National Cancer Institute. Trisomy 21. NCI Thesaurus. Code C43224.

A chromosomal abnormality consisting of the presence of a third copy of chromosome 21 in somatic cells. 